\title{
Phytochemical analysis and cytotoxic activity of Petiveria alliacea (Phytolaccaceae)
}

\author{
Queitilane de Souza Sales ${ }^{1}$, Fernanda Manhães Braga Gonçalves'1, \\ Amaro Chaves Ramos ${ }^{1}$, Marina Meirelles Paes², Maria Raquel \\ Garcia Vega', Milton Masahiko Kanashiro², Rodrigo Rodrigues de \\ Oliveira1
}

\begin{abstract}
${ }^{1}$ Laboratório de Ciências Químicas, Centro de Ciência e Tecnologia, Universidade Estadual do Norte Fluminense Darcy Ribeiro, Avenida Alberto Lamego, 2000, Horto - 28013-602, Campos dos Goytacazes, Rio de Janeiro, Brasil. ${ }^{2}$ Laboratório de Biologia do Reconhecer, Centro de Biociências e Biotecnologia, Universidade Estadual Norte Fluminense Darcy Ribeiro, Avenida Alberto Lamego, 2000, Horto - 28013-602, Campos dos Goytacazes, Rio de Janeiro, Brasil

Abstract: Petiveria alliacea (Phytolaccaceae) is a small shrub which grows in Africa and tropical America, where it is popularly known as "tipim", "tipi" and "guiné". The leaves are used in folk medicine as diuretic, sedative or analgesic. Phytochemical investigation led to the identification of eight compounds, six of which are being described for the first time in this species: stigmasterol, stigmastenol, stigmastanol, loliolide, 3-hydroxy-5,6-epoxy- $\beta$-ionone and benzyl- $\beta$-glucopyranoside. The hexane and dichloromethane fractions presented good antitumor activity besides low toxicity. The compounds isolated from the above mentioned fractions were also tested and showed good antitumor activity, which confirms a significant potential of steroids as antitumor agents. These results indicate the potential of $P$. alliace $a$ as source of antitumor agents.
\end{abstract}

Keywords: Phytolaccaceae, Petiveria alliacea, Steroids, Antitumor Activity

\section{INTRODUCTION}

Petiveria alliacea (Phytolaccaceae) is an herbaceous plant with a typical height of about $1 \mathrm{~m}$ found in Africa and tropical America. In Brazil, this species occurs in north, south and southeast regions, being popularly known as "tipim", "tipi", "guiné" and "erva-de-alho" (Zoghbi et al. 2002; Neves et al. 2006; Camargo 2007).

Previous ethnopharmacological studies evince the utilization of this plant as diuretic, sedative, analgesic, abortive, in the treatment of rheumatism, diabetes, headaches, allergies and furunculosis (Ruffa et al. 2002; Duarte and Lopes 2005; Camargo 2007; Oliveira; De Oliveira; Andrade 2010; Almeida 2011; Fletes-Arjona et al. 2013).

Other studies also report inhibitory effect against Trypanosoma cruzi, insecticidal activity, acaricide activity, besides antimicrobial activity against some strains, such as: Escherichia coli, Staphylococcus aureus, Enterococcus faecalis, Pseudomonas aeruginosa, Bacillus subtilis, Streptococcus mutans, Stphylococcus epidermidis, Candida parapsilosis, Candida kefyr, Candida albicans, Cladosporium cladosporioides and Cladosporium sphaerospermum. Pharmacological studies for this species show significant antileukemic , antitumor and anticonvulsant activity (Johnson; Williams; Roberts 1997; Benevides et al. 2001; Kubec and Musah 2001; Ruffa et al. 2002; Duarte and Lopes, 2005; Camargo, 2007; Webster et al. 2008; Guedes et al. 2009; Oliveira; De Oliveira; Andrade, 2010; Almeida, 2011; Pacheco et al. 2013).

The chemical profile of $P$. alliacea is characterized by the presence of sulfur containing compounds such as sulfides, polysulfides, and sulfoxides, in addition to flavonoids, steroids and triterpenes (Anwar et al. 2008; Almeida 2011; Hernández et al. 2014).

This article is published under the terms of the Creative Commons Attribution License 4.0 Author(s) retain the copyright of this article. Publication rights with Alkhaer Publications. Published at: http://www.ijsciences.com/pub/issue/2016-04/

DOI: 10.18483/ijSci.1000; Online ISSN: 2305-3925; Print ISSN: 2410-4477 
Pharmacological investigations of the ethyl acetate extract of $P$. alliacea demonstrated antitumor activity against melanoma (A375; $\left.\mathrm{IC}_{50} 35.2 \mu \mathrm{g} / \mathrm{mL} \pm 1.35\right)$, erythroleukemia (K562; IC $5032.0 \mu \mathrm{g} / \mathrm{mL} \pm 1.64)$, myeloid leukemia (NB-4; $\mathrm{IC}_{50} 45 \mu \mathrm{g} / \mathrm{mL} \pm 2.0$ ) and breast adenocarcinoma (4T1; IC $\left.\mathrm{C}_{50} 29.3 \mu \mathrm{g} / \mathrm{mL}\right)$ (Urueña et al. 2008; Cifuentes et al. 2009; Hernández et al. 2014).

This paper presents the identification of eight compounds, six of which are described for the first time occurring in this species: stigmasterol, stigmastenol, stigmastanol, loliolide, 3-hydroxy-5,6epoxy- $\beta$-ionone and benzyl $\beta$-glucopyranoside. Moreover, antitumor activity of the extracts and substances against histiocytic lymphoma (U937) were evaluated, besides cytotoxicity on peripheral blood mononuclear cells (PMBC).

\section{MATERIAL AND METHODS GENERAL EXPERIMENTAL PROCEDURE}

High performance countercurrent chromatographs (HPCCC) were acquired using a Dynamic Spectrum HPCCC apparatus (Berkshire, United Kingdom) equipped with a pair of preparative columns with 142 $\mathrm{mL}$ capacity and a pair of analytical columns with $27.5 \mathrm{~mL}$ capacity. The $\beta$-value ranges from 0.52 to 0.86 and the revolution speed was set up to $1600 \mathrm{rpm}$. The system comprises two Knauer Smartline 100 V5010 pumps (Berlin, Germany), a Buchi C-660 fraction collector and a $5 \mathrm{~mL}$ manual injection valve (Hichrom - Bellefonte, USA). The solvent system was chosen by the shake-flask method as described by Berthod and Carda-Broch (2004).

GC-MS analysis was performed on a Shimadzu GCMS-QP5050A (Kyoto, Japan) equipped with a DB5 column (30 m x $0.25 \mathrm{~mm}, 0.25 \mu \mathrm{m}$ film thickness); a flow of $1.3 \mathrm{~mL} / \mathrm{min} ; 280^{\circ} \mathrm{C}$ injector initial temperature; ion source temperature equal to $280^{\circ} \mathrm{C}$ and $70 \mathrm{eV}$ EI ionization. Sample injections were $1 \mu \mathrm{L}$.

NMR spectra were acquired on a Bruker DPX-500 model operating at $500 \mathrm{MHz}$ for ${ }^{1} \mathrm{H}$ and $125 \mathrm{MHz}$ for ${ }^{13} \mathrm{C}$, using deuterated solvents.

Column chromatography (CC) was conducted with silica-gel 60 (0063-0200 mm Merck, Germany) in glass columns with various lengths and widths. TLC analyses were performed using GF254 silica-gel 60 (Merck, Germany) revealed by different chemical and physical methods.

\section{PLANT MATERIAL}

$P$. alliacea leaves were collected at Campos dos Goytacazes (Rio de Janeiro, Brazil) in May 2013. A voucher specimen (H8389) was deposited in the herbarium of the Northern Rio de Janeiro State University.

\section{EXTRACTION AND ISOLATION}

Dried and ground leaves (1735.89 g) were submitted to Soxhlet extraction with methanol for $24 \mathrm{~h}$. The methanolic extract (70 g) was fractionated by liquidliquid partition with different organic solvents yielding four fractions: $n$-hexane $(32.71 \mathrm{~g})$, dichloromethane $(7.53 \mathrm{~g})$, ethyl acetate $(6.67 \mathrm{~g})$ and n-butanol (9.29 g).

The hexane fraction ( $3 \mathrm{~g}$ ) was chromatographed on silica gel with $n$-hexane: ethyl acetate gradients. TLC analysis of fraction 7 revealed the presence of impurities that were removed by solubilization in ethyl acetate yielding a white solid 1 (46.4 mg). Fraction 10 also revealed the presence of impurities that were removed by solubilization in methanol yielding a white solid 2 (37.6 mg).

The dichloromethane fraction $(3 \mathrm{~g})$ was submitted to silica gel chromatography eluted using $n$-hexane: ethyl acetate gradients, yielding fractions 7 (3 - 33.2 $\mathrm{mg})$ and $14(64.7 \mathrm{mg})$. Fraction 14 was submitted to HPCCC using a solvent system comprising $n$-hexane: ethyl acetate: $\mathrm{MeOH}: \mathrm{H}_{2} \mathrm{O}$ (5:6:5:6; v/v). The upper mobile phase was eluted by flow $1.5 \mathrm{~mL} / \mathrm{min}$ from the tail-to-head, bloodletting of $16 \mathrm{~mL}$ and sample elution time $02.30 \mathrm{~min}$. Compound 4 (10.6 mg) was isolated as a yellow oil.

The ethyl acetate fraction ( $1 \mathrm{~g}$ ) was partitioned using a two-phase solvent system comprising $n$-hexane: ethyl acetate: $\mathrm{MeOH}: \mathrm{H}_{2} \mathrm{O}$ (1:2.5:1:2.5; v/v), resulting in two fractions: an organic upper phase $(607 \mathrm{mg})$ and an aqueous lower phase $(393 \mathrm{mg})$.

The aqueous lower phase (143.1 mg) was submitted to HPCCC using a solvent system comprising acetonitrile: ethyl acetate: iso-butanol: $\mathrm{H}_{2} \mathrm{O}$ $(0.5: 3: 2: 5 ; \mathrm{v} / \mathrm{v})$. The lower mobile phase was eluted by flow $1.5 \mathrm{~mL} / \mathrm{min}$ from the head-to-tail, bloodletting of $24 \mathrm{~mL}$ and sample elution time 02.30 min. Compound 5 (8.3 mg) was obtained as a yellow solid.

\section{$3 \beta$-isoarborinol $(\mathbf{1})$}

Compound 1: ${ }^{1} \mathrm{H}$ NMR (500 MHz, $\left.\mathrm{CDCl}_{3}\right): 3.23$ (d, $J$

$=4.6 \mathrm{~Hz}, \mathrm{H}-3), 5.25(\mathrm{~d}, J=5.5 \mathrm{~Hz}, \mathrm{H}-11), 1.62(\mathrm{~d}, J$

$=6.5 \mathrm{~Hz}, \mathrm{H}-18) ;{ }^{13} \mathrm{C} \mathrm{NMR}\left(125 \mathrm{MHz}, \mathrm{CDCl}_{3}\right): 35.9$

(C-1), 27.7 (C-2), 78.9 (C-3), 39.0 (C-4), 52.3 (C-5),

21.4 (C-6), 26.6 (C-7), 40.9 (C-8), 148.8 (C-9), 39.6

(C-10), 114.3 (C-11), 36.0 (C-12), 36.7 (C-13), 38.1

(C-14), 29.7 (C-15), 35.9 (C-16), 42.8 (C-17), 52.0

(C-18), 20.1 (C-19), 28,2 (C-20), 59.6 (C-21), 30.7

(C-22), 28.2 (C-23), 15.6 (C-24), 22.1 (C-25), 17.0

(C-26), 15.2 (C-27), 13.9 (C-28), 22.1 (C-29) e 23.0 
(C-30). GC-MS - retention time $30.04 \mathrm{~min}, \mathrm{M}^{+}$426, $\mathrm{C}_{30} \mathrm{H}_{50} \mathrm{O}, \mathrm{m} / \mathrm{z} 411,393,273,259,241,191,163$.

loliolide (4a) and 3-hydroxy-5,6-epoxy- $\beta$-ionone (4b) Compound 4a: ${ }^{1} \mathrm{H}$ NMR (500 MHz, $\left.\mathrm{CDCl}_{3}\right)$ : $4.34(\mathrm{~m}$, $\mathrm{H}-3), 5.70(\mathrm{~s}, \mathrm{H}-7), 2.00(\mathrm{dd}, J=17.0 \mathrm{~Hz}$ e $3.5 \mathrm{~Hz}$, $\left.\mathrm{H}_{\mathrm{a}}-2\right), 1.55$ (dd, $J=14 \mathrm{~Hz}$ e $\left.3.5 \mathrm{~Hz}, \mathrm{H}_{\mathrm{b}}-2\right), 2.49$ (dd, $J$ $=14.0 \mathrm{~Hz}$ e $\left.2.5 \mathrm{~Hz}, \mathrm{H}_{\mathrm{a}}-4\right), 1.80\left(\mathrm{~s}, \mathrm{H}_{\mathrm{b}}-4\right) ;{ }^{13} \mathrm{C} \mathrm{NMR}$ (125 MHz, $\left.\mathrm{CDCl}_{3}\right): 35.9$ (C-1), $47.3(\mathrm{C}-2), 66.8(\mathrm{C}-$ 3), 45.6 (C-4), 86.7 (C-5), 182.5 (C-6), 112.9 (C-7), 171.9 (C-8), 26.5 (C-9), 30.6 (C-10), 19.8 (C-11); CG-MS - 4a, 28.27\%, retention time $6.36 \mathrm{~min}, \mathrm{M}^{+}$ 197, $\mathrm{C}_{11} \mathrm{H}_{16} \mathrm{O}_{3}, \mathrm{~m} / \mathrm{z} 191,123,109,95$ e 79.

Compound 4b: ${ }^{1} \mathrm{H}$ NMR (500 MHz, $\left.\mathrm{CDCl}_{3}\right): 3.92$ (m, H-3), 7.05 (d, $J=15.9 \mathrm{~Hz}, \mathrm{H}-7), 6.31$ (d, $J=15.9 \mathrm{~Hz}$, $\mathrm{H}-8), 1.65\left(\mathrm{~s}, \mathrm{H}_{\mathrm{a}}-2\right), 1.26\left(\mathrm{~s}, \mathrm{H}_{\mathrm{b}}-2\right), 2.40(\mathrm{dd}, J=6.5$ $\mathrm{Hz}$ e $\left.1.5 \mathrm{~Hz}, \mathrm{H}_{\mathrm{a}}-4\right), 1.68\left(\mathrm{~s}, \mathrm{H}_{\mathrm{b}}-4\right) ;{ }^{13} \mathrm{C}$ NMR (125 $\left.\mathrm{MHz}, \mathrm{CDCl}_{3}\right)$ : 35.1 (C-1), 46.6 (C-2), 64.0 (C-3), 40.5 (C-4), 67.2 (C-5), 69.4 (C-6), 142.4 (C-7), 132.6 (C-8), 197.5 (C-9), 28.2 (C-10), 24.9 (C-11), 27.0 (C12), 29.3 (C-13); CG-MS - 4b, 71.63\%, retention time 7.03 min, $\mathrm{M}^{+} 255, \mathrm{C}_{13} \mathrm{H}_{20} \mathrm{O}_{3}, \mathrm{~m} / \mathrm{z} 196,178,163$, $140,124,111$ e 95.

\section{Benzyl- $\beta$-glucopyranoside (5)}

Compound 5: ${ }^{1} \mathrm{H}$ NMR (500 MHz, MeOD): 7.36 (m, H-2 e 6), 7.41 (m, H-3 e 5), 7.29 (m, H-4), 4.37 (d, $J$ = $8.3 \mathrm{~Hz}, \mathrm{H}-1$ "), 3.27 (m, H-2”), 3.28 (m, H-3"), 3.38 (m, H-4"), 3.41 (m, H-5"), 4.95 (d, J = $11.9 \mathrm{~Hz}, \mathrm{H}_{\mathrm{a}}$ 1'), 4.69 (d, $J=11.9 \mathrm{~Hz}, \mathrm{H}_{\mathrm{b}}-1$ '), 3.71 (s, $\mathrm{H}_{\mathrm{a}}-6$ '), 3.91 (s, H $\mathrm{H}_{\mathrm{b}}-6$ "); ${ }^{13} \mathrm{C}$ NMR (125 MHz, MeOD): 137.68 (C1), 127.80 (C-2 e 6), 127.88 (C-3 e 5), 127.29 (C-4), 70.35 (C-1'), 101.89 (C-1”), 73.75 (C-2”), 76.64 (C3"), 70.31 (C-4”), 76.71 (C-5”), 61.43 (C-6”).

\section{CYTOTOXICITY AGAINST TUMOR CELL LINES}

The MTT assay used to evaluate the antitumor potential of the leaves extracts (Mosmann, 1983) against human cancer cell line U937 (histiocytic lymphoma) was purchased from American Type Culture Collection (ATCC, Rockiville, MD, USA) and that against human normal cell line (PBMC) peripheral blood mononuclear cells was obtained from the venous blood of healthy volunteers (Bennett and Breit, 1994). Cytotoxicity analysis of the fractions and compounds were quantified by assessing the ability of living cells to reduce the yellow dye 3-(4,5-dimethyl-2-thiazolyl)-2,5diphenyl-2H-tetrazolium bromide (MTT) to a purple formazan product. All cell lines were maintained in DMEM-F12 medium $\left(\right.$ Gibco $\left.^{\circledR}\right)$ supplemented with $10 \%$ fetal bovine serum and $20 \mu \mathrm{g} / \mathrm{mL}$ gentamicin $\left(\mathrm{Gibco}^{\circledR}\right)$ at $37^{\circ} \mathrm{C}$ with $5 \% \quad \mathrm{CO}_{2}$ and controlled humidity. Cells were plated in 96-well plates 100 $\mu \mathrm{L} /$ well $\left(1 \times 10^{6}\right.$ cells $\left./ \mathrm{mL}\right)$ and incubated with various concentrations of fractions and compounds. After 48 h of incubation, $20 \mu \mathrm{L}$ of MTT $(10 \mathrm{mg} / \mathrm{mL})$ was added to each well plate. Plates were maintained at $37^{\circ} \mathrm{C}$ with $5 \% \mathrm{CO}_{2}$ and controlled humidity for $4 \mathrm{~h}$. After this period, $150 \mu \mathrm{L}$ of the supernatant were removed from each well and $100 \mu \mathrm{L}$ of a $0.0014 \%$ solution of $\mathrm{HCl}$ in isopropanol, was added and homogenize until complete dissolution of the purple formazan. After centrifugation for $10 \mathrm{~min}$, at 1500 $\mathrm{rpm}, 100 \mu \mathrm{L}$ of the supernatant was transferred to another 96-well culture plate in order to measure absorbance at $570 \mathrm{~nm} \quad\left(\right.$ Epoch $^{\mathrm{TM}}$, BioTek ${ }^{\circledR}$ Instruments, Inc.). Doxorubicin (Sigma Aldrich) was used as positive control for the tested cell lines.

\section{STATISTICAL ANALYSIS}

Cell viability was evaluated by two-way ANOVA (analysis of variance). The means and respective standard errors were analyzed using the Graph Pad software Prism version 5.0 (GraphPad Software Incorporated, San Diego, USA). Significant difference was $\mathrm{p}<0.5,<0.01$ and $<0.001$.

\section{RESULTS AND DISCUSSION}

Phytochemical analysis afforded the identification of one triterpene: 3 $\beta$-isoarborinol (1); four steroids: stigmasterol (3a), stigmastenol (3b), $\beta$-sitosterol (3c) stigmastanol (3d), which were isolated both from the hexane and dichloromethane fractions; two norsesquiterpenoids: loliolide (4a) and 3-hydroxy5,6 -epoxy- $\beta$-ionone (4b) and one phenolic glycoside benzyl- $\beta$-glucopyranoside (5) (Figure 1).

Structures were identified based on NMR spectral results and comparison with published data: triterpene 1 (Flagg 200), steroids mixture 3 (Itoh et al. 1981; Kojima et al. 1990) (TABLE 1), norsesquiterpenoids $\mathbf{4 a}$ and $\mathbf{4 b}$ (Chávez et al. 1997) and phenolic glycosides 5 (Yoneda et al. 2008). Triterpene, mixture of steroids and mixture of norsesquiterpenoids were also analyzed by GC-MS. 


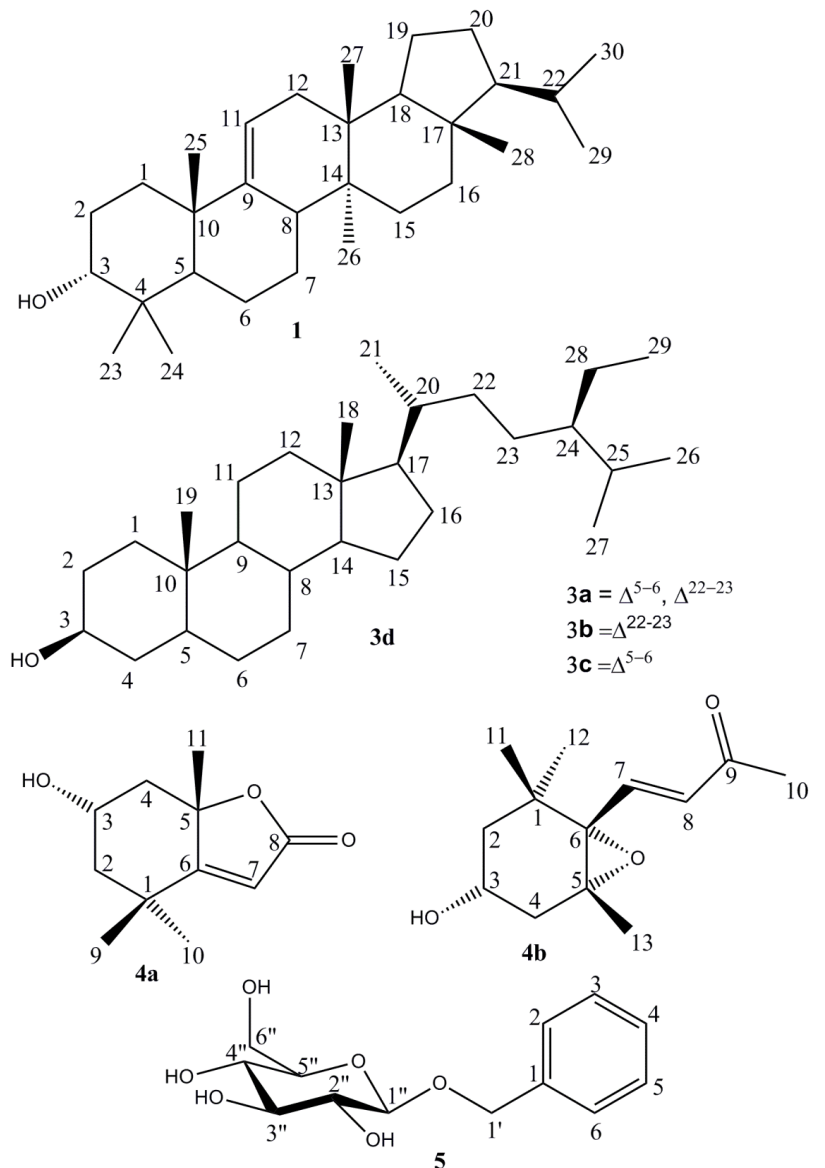

GC-MS analysis of the steroidal fractions allowed the identification of: stigmasterol (3a - 15.9\%) Retention time 20.9 min., $\mathrm{M}^{+} 412$, fragmented ions $\mathrm{m} / \mathrm{z}$ 394, 351, 300, 273 and 255, molecular formula $\mathrm{C}_{29} \mathrm{H}_{48} \mathrm{O}$; stigmastenol (3b - 21.4\%) - Retention time 21:2 min., $\mathrm{M}^{+}$414, fragmented ions $\mathrm{m} / \mathrm{z} 399,371$, 353, 316, 302, 287 and 273, molecular formula $\mathrm{C}_{29} \mathrm{H}_{50} \mathrm{O} ; \beta$-sitosterol $(3 \mathbf{c}-12.87 \%)$ - Retention time 22:5 min., $\mathrm{M}^{+}$414, fragmented ions $\mathrm{m} / \mathrm{z} 396,329$, $303,273,255,231$ and 213, molecular formula $\mathrm{C}_{29} \mathrm{H}_{50} \mathrm{O}$ and stigmastanol (3d - 49.83\%) - Retention time 22:8 min., $\mathrm{M}^{+} 416$, fragmented ions $\mathrm{m} / \mathrm{z} 401$, 383, 233 and 215, molecular formula $\mathrm{C}_{29} \mathrm{H}_{52} \mathrm{O}$.

The ${ }^{1} \mathrm{H}$ NMR spectrum of compound 5 spectrum presented signals between $\delta_{H} 7.2$ - $7.4 \mathrm{ppm}$ which are characteristic of aromatic protons. Aromatic carbons were also detected in ${ }^{13} \mathrm{C}$ NMR spectrum: $\delta_{\mathrm{C}} 137.68$ and 127.29 ppm. Glycosidic signals between $\delta_{\mathrm{H}} 3.6-$ $3.9 \mathrm{ppm}$ were also observed in ${ }^{1} \mathrm{H} \mathrm{NMR}$, and a doublet at $\delta_{\mathrm{H}} 4.37$ (d, $8.3 \mathrm{~Hz}, \mathrm{H}-1$ ") was assigned as the anomeric proton. An anomeric carbon was also observed in ${ }^{13} \mathrm{C}$ NMR at $\delta_{\mathrm{C}} 101.89$ (C-1") in addition to five signals between $\delta_{\mathrm{C}} 61.0-77.0 \mathrm{ppm}$ which suggest the presence of a glycoside moiety. The analysis of the spectral data compared with literature data confirmed benzyl- $\beta$-glucopyranoside structure (Yoneda

et al.

2008).

Figure 1 - Structures of identified compounds from $P$. alliacea leaves.

Table 1 - Spectral data for the mixture compounds identified $(3)\left({ }^{13} \mathrm{C}: 125 \mathrm{MHz}\right.$; in $\left.\mathrm{CDCl}_{3}\right)($ Itoh et al. 1981 ; Kojima et al. 1990).

\begin{tabular}{c|c|c|c|c}
\hline $\mathbf{N}^{\mathbf{0}} \mathbf{C}$ & $\mathbf{3 a}$ & $\mathbf{3 b}$ & $\mathbf{3 c}$ & $\mathbf{3 d}$ \\
\hline $\mathbf{C}$ & $\boldsymbol{\delta}_{\mathbf{c}}$ & $\boldsymbol{\delta}_{\mathbf{c}}$ & $\boldsymbol{\delta}_{\mathbf{c}}$ & $\boldsymbol{\delta}_{\mathbf{c}}$ \\
\hline 5 & & & & - \\
\hline 10 & 140,7 & - & 140,7 & 36,5 \\
\hline 13 & 36,5 & 36,5 & 36,1 & 42,2 \\
\hline $\mathbf{C H}$ & & 42,2 & 42,3 & \\
\hline 3 & 71,7 & & & 71,7 \\
\hline 5 & - & - & 71,7 & 40.0 \\
\hline 6 & 121,7 & - & - & - \\
\hline 8 & 31,9 & 31,9 & 31,9 & 31,9 \\
\hline 9 & 50,1 & 50,1 & 50,1 & 50,1 \\
\hline 14 & 56,8 & 56,8 & 56,8 & 56,8 \\
\hline 17 & 55,9 & 55,9 & 56,1 & 55,9 \\
\hline 20 & 40,5 & 36,5 & 36,5 & 40,5 \\
\hline 22 & 138,3 & 138,3 & - & - \\
\hline 23 & 129,2 & 129,2 & - & - \\
\hline 24 & 51,2 & 51,2 & 45,8 & 51,2 \\
\hline 25 & 31,9 & 31,9 & 28,9 & 31,9 \\
\hline $\mathbf{C H} \mathbf{2}$ & & & & 37,2 \\
\hline 1 & 37,2 & 37,2 & 37,2 & 31,6 \\
\hline 2 & 31,6 & 31,6 & 31,9 & 42,3 \\
\hline 4 & 42,3 & 42,3 & 42,3 & 29,6 \\
\hline 6 & - & 29,8 & - &
\end{tabular}




\begin{tabular}{c|c|c|c|c}
\hline 7 & 31,8 & 31,8 & 31,6 & 31,8 \\
\hline 11 & 21,1 & 21,1 & 21,1 & 21,1 \\
\hline 12 & 39,7 & 39,7 & 39,9 & 39,7 \\
\hline 15 & 24,3 & 24,3 & 24,3 & 24,3 \\
\hline 16 & 28,9 & 28,9 & 28,2 & 28,9 \\
\hline 22 & - & - & 34,2 & 34,2 \\
\hline 23 & - & - & 26,0 & 26,0 \\
\hline 28 & 25,4 & 25,4 & 23,0 & 25,4 \\
\hline $\mathbf{C H}_{3}$ & & & & \\
\hline 18 & 12,0 & 12,0 & 11,8 & 12,0 \\
\hline 19 & 19,4 & 19,4 & 19,4 & 19,4 \\
\hline 21 & 21,2 & 21,2 & 19,0 & 21,2 \\
\hline 26 & 21,1 & 21,1 & 19,8 & 21,1 \\
\hline 27 & 19,0 & 19,0 & 18,8 & 19,0 \\
\hline 29 & 12,3 & 12,3 & 12,0 & 12,3 \\
\hline
\end{tabular}

The methanol extract and fractions of this extract were tested for cytotoxicity activity front cell lines U937 and PBMC (Table 2).

According to the American National Cancer Institute, $\mathrm{IC}_{50}$ of $30 \mu \mathrm{g} \cdot \mathrm{mL}^{-1}$ is the upper limit for an crude extract or fraction there of to be considered a potential antitumor drug (Suffness and Pezzuto 1990). The best antitumor activity was found on the achieved by hexane and dichloromethane fractions, $\mathrm{IC}_{50} 29.91 \mu \mathrm{g} / \mathrm{mL} \pm 1.09$ and $24.89 \mu \mathrm{g} / \mathrm{mL} \pm 1.16$, respectively. These fractions also showed low cytotoxicity in PBMC, 94.61 $\pm 1.22 \mu \mathrm{g} / \mathrm{mL}$ and $\mathrm{IC}_{50}$ $117.2 \pm 1.24 \mu \mathrm{g} / \mathrm{mL}$. Thus, the phytochemical investigation was focused on these fractions and the isolated compounds were also evaluated against U937 and PBMC (Table 3).
The pure compound isolated from the hexane fraction (1 - 3 $\beta$-isoborinol) did not show any antitumor activity, where as the steroid mixture (3) demonstrated significant activity against U937 (IC 50 $26.10 \pm 1.07 \mu \mathrm{g} / \mathrm{mL}$ ) with low cytotoxicity for peripheral blood mononuclear cells ( IC $_{50}$ with 211.3 $\pm 1.04 \mu \mathrm{g} / \mathrm{mL})$.

This steroid mixture is formed by unique skeleton type with different unsaturation standard. The literature records that steroids exhibit activity against leukemia breast, prostate, colon, lung, stomach and ovarian cancer with low cytotoxicity for the normal cells (Sayeed and Ameen 2015). The anticancer activity of $P$. alliacea described by Urueña, Cifuentes and Hernández may be as cribbed to the presence of steroids as described previously.

Table $2-\mathrm{IC}_{50}$ values extract / fractions of the species $P$. alliacea in neoplastic and normal cells after incubation for 48 hours.

\begin{tabular}{c|c|c}
\hline \multirow{2}{*}{ Extract and fractions } & \multicolumn{2}{|c}{ IC $_{\mathbf{5 0}}(\boldsymbol{\mu g} / \mathbf{m L})^{*}$} \\
\cline { 2 - 3 } & U937 & PBMC \\
\hline PAM & $98.97 \pm 1.19$ & $253.3 \pm 1.07$ \\
\hline PAMH & $29.91 \pm 1.09$ & $94.61 \pm 1.22$ \\
\hline PAMD & $24.89 \pm 1.16$ & $117.2 \pm 1.24$ \\
\hline PAMA & $81.46 \pm 1.16$ & $161.4 \pm 1.16$ \\
\hline PAMB & $>400$ & $>400$ \\
\hline
\end{tabular}

* The data are presented as $\mathrm{IC}_{50}$ values. The experiments were performed in triplicate.

Table $3-\mathrm{IC}_{50}$ values of the substances identified in the species $P$. alliacea in neoplastic and normal cells after incubation for 48 hours.

\begin{tabular}{c|c|c}
\hline \multirow{2}{*}{ Substances identified } & \multicolumn{2}{|c}{ IC $_{\mathbf{5 0}}(\boldsymbol{\mu} \mathbf{g} / \mathbf{m L})^{*}$} \\
\cline { 2 - 3 } & $\mathrm{U} 937$ & PBMC \\
\hline 1 & $>200$ & $>200$ \\
\hline 3 & $26.10 \pm 1.07$ & $26.92 \pm 1.3 \pm 1.04$ \\
\hline Doxorubicin (positive control) & $2.25 \pm 1.03 \mu \mathrm{M}$ & \\
\hline
\end{tabular}

*The data are presented as $\mathrm{IC}_{50}$ values. Doxorubicin was used as positive control. The experiments were performed in triplicate. 


\section{CONCLUSION}

Eight compounds were identified in this study, namely, one triterpene, four steroids, two norsesquiterpenoids and one phenolic glycoside. Six of the eight substances are described here for the first time in the species $P$. alliacea (stigmasterol, stigmastenol, stigmastanol, loliolide, 3-hydroxy-5,6epoxy- $\beta$-ionone and benzyl- $\beta$-glucopyranoside). In the cytotoxic activity assay we found that the hexane and dichloromethane fractions presented excellent antineoplastic activity and low toxicity. The tests performed with the compounds obtained by these fractions confirm the antineoplastic potential of the steroid class.

\section{ACKNOWLEDGMENTS}

The authors are grateful to FAPERJ for financial support and to CAPES for scholarships. Marina Meirelles Paes "Bolsista da CAPES - Proc. $\mathrm{n}^{\circ}$ BEX 8907/14-5."

\section{RESUMO}

Petiveria alliacea (Phytolaccaceae) é um arbusto pequeno que ocorre na África e na América tropical e é popularmente conhecido como tipim, tipi e guiné. Suas folhas são usadas pela medicina popular como diurético, sedativo, analgésico, entre outras utilizações. A investigação fitoquímica levou à identificação de oito substâncias, das quais seis estão sendo descritas pela primeira vez nessa espécie: estigmasterol, estigmastenol, estigmastanol, loliolideo, 3-hidroxi-5,6-epoxi- $\beta$-lonona e benzil- $\beta$ glucopiranosideo. As frações hexânica e diclorometânica apresentaram boa atividade antitumoral, além de baixa toxicidade. As substâncias obtidas a partir das frações acima mencionadas, também foram testadas e mostraram boa atividade antitumoral, o que confirma o grande potencial dos esteróides como agentes antitumorais. Estes resultados indicam o potencial de $P$. alliacea como fonte de agentes antitumorais.

Palavras-chave: Phytolaccaceae, Petiveria alliacea, esteroides, atividade antitumor.

\section{REFERENCES}

1) ALMEIDA M Z. 2011. Plantas medicinais. 3th ed., Salvador/Bahia: Ed. EDUFBA, $221 \mathrm{p}$.

2) ANWAR A, BURKHOLZ T, SCHERER C, ABBAS M, LEHR C M, DIEDERICH M, JACOB C. 2008. Naturally occuring reactive súlfur species, their activity against Caco-2 cells, and possible modes of biochemical action. J Sulfur Chem 29: 251-268.

3) BENNETT S, BREIT S N. 1994. Variables in the isolation and culture of human monocytes that are of particular relevance to studies of HIV. J Leukoc Biol 56: 236-240.

4) BENEVIDES, P. J. C.; YOUNG, M. C. M.; GIESBRECHT, A. M.; ROQUE, N. F.; BOLZANI, V. S. 2001. Antifungal polysulphides from Petiveria alliacea L. Phytochemistry 57: 743-747
5) BERTHOD A AND CARDA-BROCH S. 2004. Determination of liquid-liquid partition coefficients by separation methods. J Chromatogr A 1037: 3-14.

6) CAMARGO M $\mathrm{T}$ L A. 2007. Contribuição etnofarmacobotânica ao estudo de Petiveria alliacea L. Phytolaccaceae - ("amansa-senhor") e a atividade hipoglicemiante relacionada a transtornos mentais. Dominguezia 23.

7) CIFUENTES M C, CASTAÑEDAD M, URUEÑA C P, FIORENTINO S. 2009. A fraction from Petiveria alliacea induces apoptosis via a mitochondria-dependent pathway and regulates HSP70 expression. Univ Sci 14: 125-134.

8) CHAVÉZ, J. P.; SANTOS, I. D.; CRUZ, F. G.; DAVID, J. M.; YANG, S. W.; CORDELL, G. A. 1997.A quinoline alkaloid from acanthosyris Paulo-Alvinii. Phytochemistry 46: 5: 967-968.

9) DUARTE M R AND LOPES J F. 2005. Leaf and stem morphoanatomy of Petiveria alliacea. Fitoterapia 76: 599607.

10) FLAGG M L. 2000. Bioprospecting, Chemical Invcstigatioas and Drug Discovery from Chilean Plants. Arizona, US. Dissertação de doutorado em Filosofia, The University of Arizona $121 \mathrm{p}$.

11) FLETES-ARJONA, V. M.; SOTO-DOMÍNGUEZ, A.; GARCÍA-GARZA, R.; MORÁN-MARTÍNEZ, J.; BENÍTEZ-VALLE，C.; CASTAÑEDA-MARTÍNEZ， A..; MONTALVO-GONZÁLEZ, R.; BECERRA-VERDÍN, E. M. 2013. Alteraciones Morfológicas en el Tracto Respiratorio de Ratas Wistar Inducidas por Vapores de la Raíz de Hierba del Zorrillo (Petiveria alliacea) del Suroeste de México. International Journal of Morphology 31: 1: 121127.

12) GUEDES, R. C. M.; NOGUEIRA, N. G. P.; FUSCOALMEIDA, A. M.; SOUZA, C. R. F.; OLIVEIRA, W. P. 2009. Atividade antimicrobiana de extratos brutos de Petiveria alliacea L. Latin American Journal of Pharmacy 28: 4: 520-524

13) HERNÁNDEZ, J. F.; URUEÑA, C. P.; CIFUENTES, M. C.; SANDOVAL, T. A.; POMBO, L. M.; CASTAÑEDA, D.; ASEA, A.; FIORENTINO, S. A. 2014. Petiveria alliacea standardized fraction induces breast adenocarcinoma cell death by modulating glycolytic metabolism. Journal of Ethnopharmacology 153: 641-649.

14) ITOH T, KIKUCHI Y, TAMURA T, MATSUMOTO. 1981 Co-occurrence of chondrillasterol end spinasterol in two cucurbitacceae seeds as shown by ${ }^{13} \mathrm{C}$ NMR. Phytochemistry 20: 761-764.

15) JOHNSON, L.; WILliAMS, L. A. D.; ROBERTS, E. V. 1997. An insecticidal and acaricidal polysulfide metabolite from the roots of Petiveria alliacea. Pesticide Science 50: 228-232.

16) KOJIMA H, SATO N, HATANO A, OGURA H. 1999. Sterol glucosides from Prunella vulgaris. Phytochemistry 29 2351-2355.

17) KUBEC, R.; MUSAH, R. A. 2001. Cysteine sulfoxide derivatives in Petiveria alliacea. Phytochemistry 58: 981985.

18) MOSMANN T. 1983 Rapid colorimetric assay for cellular growth and survival: application to proliferation and cytotoxicity assays. J lmmunol Methods 55-63.

19) NEVES P C P, BAUERMANN S G, BITENCOURT A L V, SOUZA P A, MARCHIORETTO M S, BORDIGNON S A L. 2006. Palinoflora do estado do Rio Grande do Sul, Brasil: Phytolaccaceae R. BR. Rev Bras Paleontol 9: 157-164.

20) OLIVEIRA G L, DE OLIVEIRA A F M, ANDRADE L H C. 2010. Plantas medicinais utilizadas na comunidade urbana de Muribece, Nordeste do Brasil. Acta Bot Bras 24: 571-577.

21) PACHECO, A. O.; MORÁN, J. M.; GIRO, Z. G.; RODRÍGUEZ, A. H.; MUJAWIMANA, R. J.; GONZÁLEZ, K. T.; FRÓMETA, S. S. 2013. In vitro antimicrobial activity of total extracts of the leaves of Petiveria alliacea $\mathrm{L}$. (Anamu). Brazilian Journal of Pharmaceutical Sciences 49: 2: 241-249.

22) RUFFA M J, FERRARO G, WAGNER M L, CALCAGNO 
M L, CAMPO R H, CAVALLARO L. 2002. Cytotoxic effect of Argentine medicinal plant extracts on human hepatocellular carcinoma cell line. J Ethnopharmacol 79: 335-339.

23) SAYEED B M S AND AMEEN S S. 2015. Beta Sitosterol A Promising but orphan nutraceutical to fight against cancer.Nutrition and Cance 67: 1216-1222.

24) SUFFNESS M AND PEZZUTO JM. 1990. Assays related to cancer drug discovery. In: HOSTETTMANN K(Ed), Methods in plant biochemistry: assays for bioactivity, London: Academic Press. p. 71-133.

25) URUEÑA C, CIFUENTES C, CANTAÑEDA D, ARANGO A, KAUR P, ASEA A, FIORENTINO S. 2008. Petiveria alliacea extracts uses multiple mechanisms to inhibit growth of human and mouse tumoral cells. BMC Complemet Altern Med 8: 1-17.
26) WEBSTER, S. A.; MITCHELL, S. A.; GALLIMORE, W. A.; WILliaMS, L. A. D.; AHMAD, M. H. 2008. Biosyntesis of dibenzyl trisulfide (DTS) from somatic ambryos and rhizogenous/embryogenic callus derived from Guinea hen weed (Petiveria alliacea L.) leaf explants. In Vitro Cellular \& Developmental Biology - Plant 44: 112118.

27) YONEDA Y, KRAINZ K, LIEBNER F, POTTHAST A, ROSENAU T, KARAKAWA M, NAKATSUBO F. 2008. "Furan endwise peeling" of celluloses: Mechanistic studies and application perspectives of a novel reaction. Eur J Org Chem 475-484.

28) ZOGHBI M G B, ANDRADE E H A, MAIA J G S. 2002. Volatile constituents from Adenocalymma alliaceum Miers and Petiveria alliacea L., two medicinal herbs of the Amaxzon. Flavour Fragr J 17: 133-135. 